\title{
Bi-culturalism and accountability: Fundamental changes in social work practice in Aotearoa New Zealand 1984 - 1990
}

\author{
Sarah Fraser ${ }^{1}$ and Lynne Briggs ${ }^{2}$
}

\begin{abstract}
A number of key events took place in the history of the Aotearoa New Zealand Association of Social Workers (ANZASW) in the mid-1980s and early 1990s. This article explores critical developments and debates in the lead up to the 1986 Turangawaewae conference at which the bi-cultural structure of the Association first emerged. The proceedings of the conference itself are examined and the subsequent establishment of a unique system of accountability for ANZASW members discussed. These events are considered significant in the shaping of the Association's current structure, bi-lingual Code of Ethics (ANZASW, 2015), its competency assessment processes and in its contribution to the era of professional registration.

While it is impossible to clearly delineate a beginning point, the article picks up the Association's story in 1984. It is told from the perspective of the first two Manuhiri Caucus Presidents, Sarah Fraser (1986-1988) and Lynne Briggs (1988 - 1990), and gives voice to some of the participants involved through reference to documents and communications of the time. Other than the points at which the histories of the Manuhiri (later renamed as Tau Iwi) and Tangata Whenua (later renamed as Tangata Whenua Takawaenga o Aotearoa) caucuses intersect, it is the authors' view that the important and ground breaking history of the Tangata Whenua Caucus is not theirs to relate.
\end{abstract}

KEYWORDS: Aotearoa New Zealand Association of Social Workers; history; anti-racism; accountability; bi-culturalism; registration

\section{Introduction}

O'Brien (2014) presents a strong argument that social work in Aotearoa New Zealand needs to continuously reflect on its practice in a way that is firmly grounded in an understanding of its history and development. This article contributes to the historical record of the Aotearoa New Zealand Association of Social Workers (ANZASW) through an exploration of critical developments and debates in the lead up to the 1986 Turangawaewae conference "Social Work in Te Aohurihuri" at which the bi-cultural structure of the Association first emerged. The events that took place at the conference are reviewed and the process leading to the subsequent establishment of a unique system of accountability for ANZASW members discussed.

Reflection on these aspects of the profession's history show the significance of this period for the formation of the Association's current structure, bi-lingual Code of Ethics (ANZASW, 2015) and competency assessment processes. The influence of this critical period can also be seen in the legislation and policies shaping professional registration for social workers in this country today.
${ }^{1}$ Nelson Marlborough Institute of Technology, New Zealand

${ }^{2}$ Griffith University, Australia
AOTEAROA

NEW ZEALAND SOCIAL WORK 28(1), 43-51.

CORRESPONDENCE TO: Sarah Fraser sarah.fraser@nmit.ac.nz 
The account contained here is based on Sarah Fraser's archival research (undertaken as part of her PhD study), combined with her own and Lynne Briggs' perspectives as the first two Manuhiri Caucus Presidents of what was then known as the New Zealand Association of Social Workers (NZASW). The article endeavours to give a voice to those who were present at the time through direct reference to editorials, speeches, conference proceedings and reports contained in the ANZASW archives. It is, however, acknowledged by the authors that other than the points at which the histories of the two caucuses (Manuhiri, later re-named Tau Iwi, and Tangata Whenua, later renamed as Tangata Whenua Takawaenga o Aotearoa) intersect, the ground-breaking history of the Tangata Whenua Caucus is not theirs to relate. An increasing and rich body of literature does address this important history (Ohia, 1988a; Pihama, 1991; Ruwhiu, 1999, 2002; Walsh-Tapiata, 2002).

\section{Turbulent times leading into the 1986 NZASW conference at Turangawaewae}

At the time our history begins, the total membership of the Association stood at just 450 (Tozer, 1984). There was significant concern that numbers were falling and community and youth workers were questioning whether the organisation was a good fit for them or whether they should establish separate representative bodies. Beddoe and Randal (1994) described the Association as an "organisation with a Pakeha face" (p. 23) and there was a view held by some that it was of little relevance to social workers nationally.

Competency and registration issues were already a focus of discussion (BarrettaHerman, 1994). The then Social Work Training Council (with Eve Hessey and Janette Papesch as NZASW representatives) was set to produce a document on 'Minimum competencies for Social Work in New Zealand' (New Zealand Social Work Training Council, 1984). There was widespread concern amongst the social work community about a lack of consultation in the development of this document. Independently of this, a national survey on registration had been undertaken by the Association and a report with proposals for registration of social workers was prepared for the 1984 national conference. The Association's Working Party on Racism (1984) also prepared a report for the same conference following on from the 1982 Human Rights Commission report 'Race Against Time: Institutionalised discrimination'. An editorial by Allyson Davys and Sue Kemp in the March 1984 journal, published prior to the conference, captured the essence of these debates at this point in ANZASW's history:

As social workers we must look beyond our daily practice in confronting issues of racism. Take for example the current NZASW debate on registration and accreditation. Emphasis in the debate has been given to the establishment of 'professional standards' of competence, the wish for protection of clients and the issue of possible elitism within the association. However as social workers become more active in addressing racism, it is clear that the policies of our own association must also come under scrutiny. What are the implications of registration and accreditation for Maori and Pacific Island social workers? What will be the criteria for acceptance and who will decide? And what about access to social work training, and agency recruitment and selection policies and practices? (Davys \& Kemp, 1984, p. 1).

(n.b. the above quote, and others in this article from the same time period, did not include macrons for kupu in Te Reo Māori).

The 1984 Christchurch conference was fiery and intense as the issues of registration, professionalism and racism became intertwined. The executive's proposal for registration was ultimately rejected and the Association established a Standing Committee on Racism which was charged 
with focusing on education for social workers around racism, lobbying for social change and producing resources on antiracism (Bacon, 1984).

Two new remits were passed at the Annual General Meeting, recorded for history as the famous accountability remits:

That this General Meeting of NZASW recognises the need for the establishment of a system of accountability of social workers and social work services to consumers, the public, employers and the profession.

That National Executive is instructed to set up a suitably qualified representative working party which consults all interested parties and reports back to the next AGM with a plan. (Beddoe, 1984, p. 14)

The National Executive itself became this working party and the plan became the focus of much of its work for the next two years (Murphy, 1985).

In the wider context of 1984, nine women from the Auckland Department of Social Welfare (several of whom were NZASW members) released a report identifying and challenging institutional racism within the Department (Berridge, Cowan, Cumberland, Davys, McDowell, Morgan, Riley, Ruck \& Wallis, 1984). Their ground-breaking work, later widely known as the WARAG report, is acknowledged in the widely acclaimed document Puao-Te-Ata-Tu (Ministerial Advisory committee on a Māori Perspective for the Department of Social Welfare, 1988).

The Association's work on the development of an accountability system, and work with the anti- racism movement, continued into 1985 within a context of widespread social change and upheaval. A brief examination of this context helps to frame the events that followed at Turangawaewae in 1986. Mike O'Brien, and the Association's Public Questions Committee, made submissions on the proposed changes to the Children and
Young Person's Act and on the Homosexual Law Reform Bill. Josephine Serrallach led a nuclear issues interest group which, on behalf of the Association's members, sent a letter to the French Social Work Association expressing concern about the continuing nuclear testing being carried out by France in the Pacific region, and another to the New Zealand Prime Minister supporting a proposal to set up a Peace Commission. The Association lent support to the Gay Task Force and protested to the Rugby Union about the proposed rugby tour to apartheidera South Africa. There were concerns at this time that prison officers were being appointed to residential social work positions and there were fears that Matua Whangai was to be scrapped or replaced. The Association was waiting for the opportunity to make submissions to the Royal Commission on Social Policy and work continued on the possibility of NZASW becoming a member of a federation of social service organisations as part of a strategy to ensure its survival.

An editorial in News and Views on Social Work noted that in the midst of all of this 1985 could "well be remembered as the year in which Social Work in Aotearoa New Zealand made some small tentative steps towards acknowledging the hard facts of institutional racism" (Beddoe, 1985, p. 1).

The Working Party on Accountability struggled throughout this time to come to grips with the whole area of accountability, competence and service to clients. Pressure was mounting on the Association to develop a workable system as both the Department of Social Welfare and the Social Work Training Council had set up their own working parties to look at competency and standards of practice. Social work was in danger of having the nature of its task and the qualities required of social workers determined by employing agencies rather than the profession itself. Daniels (1985) argued that:

The issue of competency presents a challenge to social work. It raises concerns about the social work task, 
about the education and training that prepares workers for that task and about the professionalism of social workers. (p. 7)

The editorial in News and Views in Social Work in August /September 1985 continued the debate within the Association by putting forward an argument against registration:

Registration, an imported model, is about status and elitism, largely based on the possession of rigid, formal qualifications(It) is a mere smokescreen of the real debate about what social work is and where we should stand in relation to our clients and the state. Registration borrows the mantle of power from other professions while pretending that we will be strong and noble enough to withstand the seduction of the system. Remove the mantle and we stand, not naked, but wearing the grey suit and tie of the oppressor. (Beddoe, August, 1985, p. 4).

\section{Social Work in Te Aohurihuri: the Turangawaewae Conference}

These debates around racism, competency, accountability, registration and the very survival of the Association set the context for the 1986 conference 'Social Work in Te Aohurihuri- Social Work in a Changing World' held at Turangawaewae Marae in the Waikato. Wally Hirsch, Race Relations Conciliator, was key note speaker and the principal themes were around the three issues of racism, accountability and survival of the association (NZASW Conference Committee report to the National Executive, 1985). The NZASW Standing Committee on Racism released a draft Bi-cultural Code of Practice (March, 1986) for members to consider and then issued a challenge to all social workers to come to the conference and debate the issues arguing that "this conference may give us our last chance to come to terms without past wrangles on registration and professionalism and move on into a challenging future unrestrained by imported models" (Standing Committee on Racism, July 1986, p. 5). The accountability working party presented their report to the membership at the Conference with facilitators from the National Council of Churches, highly regarded for their antiracism work, on hand to assist in discussions (NZASW, 1986).

Māori social workers present considered the report separately and when they returned to the conference room said nothing but turned their backs and walked out, rejecting both the proposal and the Association itself. They considered neither adequately recognised the needs of Mãori. It was an emotional moment that could have seen the end of the Association but for the goodwill and determination of both parties to find a way forward. The group which, by the end of the Conference came to be known as the Manuhiri caucus, responded to the Mãori social workers' challenge by putting together a new statement on accountability based on the following principle:

The bicultural identity of Aotearoa is based on the Treaty of Waitangi. NZASW recognises Maori people as tangata whenua of Aotearoa and affirms their right to self-determination. We also acknowledge that power over resources and decision making is held by Pakeha. Bicultural practice requires that tangata whenua and manuhiri contribute equally to policy and decision making at all levels and have an equal access to resources. In addition we recognise existing Maori Models and initiatives as alternatives to conventional monocultural practices.

We acknowledge the work of the working party [on accountability] and our responsibility for it. We consider the report must be rewritten to give full adherence to the application of the principle above in relation to the Code of Ethics, code of practice and competency.

We commit NZASW to use every available resource to promote biculturalism and actively support those engaged in anti-racism activity. (Manuhiri caucus, NZASW, 1986) 
The Māori social workers responded by saying that the statement of principle was 'right on' and that the accountability proposal should be redeveloped with equal contributions from Māori and Pākāha members of NZASW (Māori Caucus, NZASW, 1986).

From here, agreement was reached that the Association would take on a new bi-cultural structure which can now be seen as the forerunner of today's Aotearoa New Zealand Association of Social Workers- with two co-presidents (one Māori and one Manuhiri), a secretary and treasurer- one of whom would be Māori - and two delegates from each region - one Māori and one Manuhiri. The intent was for this structure to ensure the continued existence of NZASW until a series of national Māori social workers' hui could be held in 1987 at which long term decisions would be made about the nature and extent of their involvement in the Association (NZASW, 1986).

\section{The beginnings of a bi-cultural social work association}

Cathy Holland, of what became known as the Tangata Whenua Caucus, took on the role of Association Secretary and Sarah Fraser was elected the first Manuhiri President. Rahera Ohia was later confirmed as the first President from the Tangata Whenua Caucus. Cathy wrote the following comments on behalf of that caucus in the Association's post-conference newsletter:

Kia ora, congratulations to the manuhiri caucus, the birth of NZASW as a bicultural entity... I don't wish to dwell on the content that brought conference to this stance - what I want to recall are the strong feelings of the conference- the apprehension, the hopes, the warmth, the determination, the frustrations, the tears, the powerful presence within Turangawaewae, the laughter, the togetherness, the strength and that eloquent silence... The new bicultural structure of the association has come at last. (Holland, 1986, p. 1).
A series of regional hui to consult with Māori social workers around the country took place over the following months whilst the Manuhiri caucus continued with the general business of the Association (Fraser, 1987). In April 1987 a national hui for Māori social workers was held but was unable to resolve the issue of whether to maintain the Tangata Whenua caucus within the Association or establish a separate association (Ohia, 1987). A further round of consultations followed.

In the first Social Work Review of 1988 Sarah Fraser wrote, as President:

1987 was a difficult year for NZASW as we confronted our own racism and attempted to support the fledgling Tangata Whenua caucus. At our AGM in November Rahera Ohia announced that the caucus had come of age and that the Tangata Whenua social workers' choice was to stand alone and gather their strength and resources before looking at partnership with manuhiri in NZASW.

Amongst both groups there was much sadness at the parting of our ways, but at the same time excitement for the aims and goals of tangata whenua. A strong and genuine commitment was made to keep in close contact with each other and work together where appropriate (Fraser, 1988a, p. 30)

Rahera Ohia wrote in her report for the Tangata Whenua caucus in that same journal that the parting of the ways did not mean an end to the goal of bi-cultural development.

We are embarking on a course which will enable Maori social workers and volunteers to decide what contribution we will make to bi-culturalism. The Tangata Whenua and Manuhiri caucii must be able to contribute equitably if bi-culturalism is going to succeed - one cannot carry the other.

Our accountability is enhanced by this decision because we are now 
clearly accountable only to our people. Therefore the success of the move is also very dependent upon our seeking the endorsement of our respective iwi and helping them to understand the anticipated benefits of the decision.

We have expressed our thanks to NZASW for creating the forum under your organisational umbrella, where we as Maori social workers could openly discuss the issues that are important to us. You have, at times, fought hard on our behalf and we must now build on that effort and determine for ourselves what will happen from now on (Ohia, 1988b, p. 31-32).

The issue of the development of a system of accountability was not lost. The departing Tangata Whenua caucus presented a challenge to the Association to continue with its attempts to develop a Code of Practice for social work in Aotearoa (National Executive, 1988).

\section{The introduction of the NZASW 'Qualification in Social Work Practice'}

In her outgoing President's report to the 1988 Annual General Meeting Sarah Fraser wrote:

Looking back now, it is possible to see that the first year attempting to work toward a bi-cultural perspective was one of the most difficult in NZASW's history, in that it created great chasms between different groups in the Association and caused enormous conflict over our aims, objectives and structures. Although I believe we made a major step forward at this time membership of NZASW has dropped and our financial base has shrunk accordingly (Fraser, 1988b, p. 3).

In spite of the fact that the Association was in a more perilous position than ever with just 291 financial members (National Executive, 1988), the work did indeed continue. The commitment remained as strong as ever for social workers to determine their own identity (Nash, 2004). At a special general meeting held in November 1988 it was agreed to introduce a Qualification in Social Work Practice (QSWP -later to become the ANZASW Competency Certificate). Lynne Briggs (President of the Association from 1988-1990) explained to members that the qualification would be based on an assessment of competence to practice, a commitment to bi-cultural practice, the philosophy and Code of Ethics of NZASW and practical experience. The intent was that from 1989 anyone who wished to join the Association would need to have, or be in training for, the QSWP. Assessment of individual social workers was to include input from peers, consumers of the services of the social worker and their employing body (Briggs, 1988). What was particularly clear, and unique to NZASW, was that the assessment did not include a requirement for any formal university based qualification such as a diploma or degree in social work. This was a crucial point for many social workers who considered that such a requirement would have made the Association elitist by cutting out access for those who had not had opportunities for formal tertiary education. It needs to be remembered that at the time these decisions were made there were only a small number of university degree programmes in social work and no professional social work programmes in institutes of technology or wānanga.

At the same time the QSWP was introduced the Association set up a Board of Qualification (later to become the Board of Competency) appointed by and accountable to the National Executive and made up of a maximum of four NZASW members and at least three members from the public or consumer groups. The board was charged with establishing the new bi-cultural practice standards, assessing applicants, issuing and reviewing the QSWP, and training and supporting assessors (Briggs, 1988). 


\section{Developing the competency assessment process}

In 1989 the Tangata Whenua caucus returned to the Association. The same year an interim Board of Competency was appointed with Maurice McGregor as Executive Director and respected social work identities June Kendrick, Louise Nicoll, Raylee Kane, Ken Daniels and Lynne Briggs as founding members. Howard Randal was contracted as a resource person (Annual report of the Interim Board of Competency to the ANZASW national conference, 1990). The Board were very aware at this time that, although it had been mindful of the Association's bi-cultural policies, it did not include representation from the Tangata Whenua caucus who were heavily involved in their own development work.

Lynne Briggs (as President of the Association) and Maurice McGregor worked closely with John Bradley and Harry Walker (both from the Tangata Whenua Caucus) and the Hon Michael Cullen, then Minister of Social Welfare, through 1988 and 1989 to gain governmental support for the development and implementation of the competency assessment process. They were so successful the Minister allocated $\$ 10,000$ from his own budget to support the Tangata Whenua Caucus to hold regional hui at which practice competencies from a Māori perspective could be developed. A further grant of $\$ 13,500$ was received from the Health Workforce Development Fund for development work across the Association (Annual report of the Interim Board of Competency to the ANZASW national conference, 1990).

In October 1989 the Hon Michael Cullen presented the first Certificates of Competency to NZASW members. Ken Daniels spoke on behalf of the Association at that momentous event. He noted that at the inaugural conference of NZASW twenty five years earlier, the then Minister of Social Welfare had challenged the new Association to maintain and improve standards of practice.
The problem was finding a system that was not elitist, self-seeking and exclusive of certain groups. Reliance on education and training as the only criteria for standard setting was obviously found to be elitist. The new model [focuses] on yours and my practice. That practice will be required to reflect the code of ethics and the principles and philosophies of the Association. Bi-cultural practice is a key part of this (Daniels, 1989, p. 30).

In his speech the Hon Michael Cullen commented that:

It is obvious that the role of the social worker in New Zealand's welfare system is being reshaped and redefined. The last decade has thankfully put to rest the old stereotype of the social worker as a person with half a degree in psychology, a "real love for people" and a poorly concealed (and only half baked) political agenda. What we now have is a fledgling profession with a great need to establish its credentials and yet maintain its roots as a client-centred, uniquely flexible and responsive service.....

The challenge is to put in place a professional approach to things such as training and programme evaluation and accountability but at the same time to avoid the pitfalls that the creation of a 'profession' invariably brings. I am referring to the temptation to elitism and to the creation of a dependency syndrome through intervention into a situation rather than interaction with the various, often very complicated factors at work...

The certification system that you are initiating today is part of that process. My hope - and I'm sure all of yours - is that it will encourage social workers to think of themselves as professionals, with an obligation to provide a consistent standard of care, and with the confidence to reshape the profession wherever necessary to address new areas of need as they evolve (Cullen, 1989, p. 29). 
By 1991 over 100 members of NZASW had been assessed, membership of the Association was growing and a full Board of Competency had been established which included Tangata Whenua representatives Taotahi Pihama and Horiana Joyce and representatives from the community (Blagdon, 1991). In addition, a Complaints Advisory Service had been established to examine alleged breaches of the International Declaration of Ethical Principles which NZASW abided by at that time.

\section{The beginnings of the Aotearoa New Zealand Association of Social Workers' own Code of Ethics}

An updated International Federation of Social Workers (IFSW) Declaration of Ethical Principles for Social Work was passed at the 1990 Argentinian Global Social Work conference. The declaration empowered member countries of the IFSW to develop codes of ethics specific to their social, cultural and professional contexts (NZASW 1993).

Over the next three years, an Interim Ethics Committee convened by Lynne Briggs oversaw the development of the Association's first uniquely New Zealand Social Work Code of Ethics and Bi-cultural Code of Practice (Beddoe \& Randal, 1994; Briggs \& Curson, 1993). The development was undertaken by Tangata Whenua and Tauiwi, in partnership, with significant input from both the Standing Committee on Racism and John Hopkins who was contracted to pull together the wealth of material informing the finished document. Since then of course the Code of Ethics has been updated and, through the leadership of John Bradley and Turoa Haronga translated into te reo Māori (Briggs, personal communication).

\section{From the past to the present}

Building on the work of those that came before, ANZASW has continued to develop its fledgling model of bi-cultural partnership through the early part of the twenty-first century. There is now provision for equal representation on the Association's governance board from Tangata Whenua Takawaenga o Aotearoa and Tauiwi. Each year the publication of Te Komako has given a platform and voice for Māori social workers, supporting the development of indigenous approaches to practice. Under its current structure ANZASW has developed two complementary processes for competency assessment. Tangata Whenua members may choose to be assessed under the wider Association protocols or the Niho Taniwha framework developed by the Tangata Whenua Takawaenga o Aotearoa. Both are recognised under the provisions of the Social Workers Registration Act 2003 for registration of social workers.

It can be seen from the history recorded here that our attempts at creating a bi-cultural association grew from the profession's commitment in the 1980s to confronting the challenges of institutional racism and ensuring the provision of accountable, transparent and effective service to our clients, service users and communities, both Māori and Tauiwi. However, it must be acknowledged that we haven't always got it right, the work is by no means done and sadly many of the same challenges remain. How those will be addressed from here is a story still to be written - we hope that it will prove to be one we are proud to add to our Association's history.

\section{References}

Aotearoa New Zealand Association of Social Workers (2015). Code of Ethics. New Zealand: Author.

Barretta- Herman, A. (1994). Development of social work in New Zealand: 1969-1988. Part III: Social work development. Social Work Review, March 1994, 12-18.

Beddoe, E. (November 1984). The famous accountability remits. News and Views in Social Work [Newsletter of the New Zealand Association of Social Workers], 14.

Beddoe, E. (August/September 1985). Editorial. News and Views in Social Work [Newsletter of the New Zealand Association of Social Workers], 3-4.

Beddoe, E. (October/November 1985). Editorial. News and Views in Social Work October/November 1985. [Newsletter of the New Zealand Association of Social Workers], 1. 
Beddoe, L., \& Randal, H. (1994). The New Zealand Association of Social Workers: The professional response to a decade of change. In R. Mumford \& M. Nash (Eds.). Social work in action (pp 21-36). Palmerston North, New Zealand: The Dunmore Printing Company.

Berridge, D., Cowan, L., Cumberland, T., Davys, A., McDowell, $\mathrm{H}$., Morgan, J. et al (1984). Institutional racism in the Department of Social Welfare: Tamaki-makau-rau. Auckland, New Zealand: Department of Social Welfare. Retrieved from http://www.trc.org.nz/sites/trc.org.nz/files/ Institutional\%20Racism\%20WARAG.pdf

Blagdon, J. (1991). NZASW President's Report 1990-1991. In NZASW AGM minutes August 1991 [meeting minutes].

Briggs, L. (1988). New Zealand Association of Social Workers' Qualification in Social Work Practice. Social Work Review (2), 23.

Briggs, L. \& Curson, B. (1993). Foreword. In New Zealand Association of Social Workers, Code of ethics. (pp 3-5). New Zealand: Author.

Cullen, M. (1989) Speech by Hon. Dr Michael Cullen. NZSW Review, 2(2\&3), 29.

Daniels, K. (1985). The issue of competency for social work. NZSW Journal, 10(1), 5-7.

Daniels, K. (1989). Ken Daniels' speech. NZSW Review, 2(2\&3), 30

Davys, A. \& Kemp, S. (1984). Editorial. NZSW Journal, 9(1), 1.

Fraser, S. (June, 1987). Manuhiri President's report. New and Views in Social Work [Newsletter of the New Zealand Association of Social Workers], 1.

Fraser, S. (1988a). President's report. NZSW Review 1(1), 30-31.

Fraser, S. (1988b). Outgoing President's report to the 1988 Annual General Meeting. Social Work Review [Supplemental material] September 1988, 3.

Human Rights Commission New Zealand (1982). Race against time: Institutionalised discrimination. New Zealand: New Zealand Government.

Holland, C. (September, 1986). From the Māori caucus of NZASW. News and Views in Social Work [Newsletter of the New Zealand Association of Social Workers], 1.

Interim Board of Competency, Aotearoa New Zealand Association of Social Workers (1990) Annual report to the ANZASW national conference, July 1990 Nelson.

Manuhiri Caucus, NZASW (August, 1986). Statement on accountability made at Turangawaewae Marae, Ngaruawhaia, New Zealand. News and Views in Social Work [Newsletter of the New Zealand Association of Social Workers], 3.

Māori Caucus, NZASW (August, 1986). Response from Māori Caucus at Turangawaewae Marae, Ngaruawahia, New Zealand. News and Views in Social Work [Newsletter of the New Zealand Association of Social Workers], 3.

Ministerial Advisory Committee on a Māori Perspective for the Department of Social Welfare (1988). Puao-te-Ata-tu (daybreak). Wellington, New Zealand: New Zealand Government.

Murphy, J. (1985). Accountability working party annual report for 1985. In NZASW Annual General Meeting Minutes Napier [meeting minutes].

Nash, M. (2004). Social work in Aotearoa New Zealand: Its origins and traditions. In M. Connolly (Ed.),
New Zealand Social Work: Contexts and Practice (pp 32-43). Melbourne, Australia: Oxford University Press.

National Executive (1988). National Executive report. NZSW Review, 1(1), 32.

New Zealand Association of Social Workers (1988). Minutes of special general meeting NZASW Wellington 19th November 1988 [meeting minutes].

New Zealand Association of Social Workers (August, 1986). Minutes of the Annual General Meeting, 26 August 1986. News and Views in Social Work [Newsletter of the New Zealand Association of Social Workers], 7-8.

New Zealand Association of Social Workers (1993). Code of Ethics. Dunedin, New Zealand, Author.

New Zealand Association of Social Workers' Conference Committee (1985). Report to the National Executive. In NZASW National Executive minutes Wellington 7 December 1985 [meeting minutes].

New Zealand Association of Social Workers' Working Party on Racism (February 1984). News and Views in Social Work [Newsletter of the New Zealand Association of Social Workers].

New Zealand Social Workers Training Council (February, 1984). Report. News and Views [Newsletter of the New Zealand Association of Social Workers], 3-4.

O'Brien, M. (2014). The world we're in: Social work now and then. Aotearoa New Zealand Social Work, 26(2\&3), 6-16.

Ohia, R. (June 1987). Report from the Tangata Whenua President. New and Views in Social Work [Newsletter of the New Zealand Association of Social Workers], 1

Ohia, R. (1988a). Speech by Rahera Ohia on behalf of the Tangata Whenua Caucus. Social Work Review [Supplemental material] September 1988, 4.

Ohia, R. (1988b). Tangata Whenua Caucus report. NZSW Review, 1(1), 31-32.

Pihama, T. (1991). Tangata Whenua report. Social Work Review, 4(1), 26-27.

Ruwhiu, L. (1999). Ko tane pupuke. Social Work Review Te Komako III, 11, 32-37.

Ruwhiu, L. (2002). Te ripota o Te Kaiwhakahaere- Tangata Whenua Takawaenga o Aotearoa. Social Work Review Te Komako, XIV(2), 3-7.

Standing Committee on Racism (March, 1986). Draft principles and bi-cultural code of practice prepared for the Accountability Working Party. News and Views in Social Work [Newsletter of the New Zealand Association of Social Workers, 8-9.

Standing Committee on Racism (July, 1986). A challenge to social workers. News and Views in Social Work. [Newsletter of the New Zealand Association of Social Workers], 5 .

Tozer, G. (1984). President's message. News and Views in Social Work [Newsletter of the New Zealand Association of Social Workers].

Walsh-Tapiata, W. (2002). Editorial. Social Work Review Te Komako, XIV(2), 1-2. 